TELAGA BAHASA

Volume 5

No. 1 Juni 2017

Halaman 83-106

\title{
KAJIAN LEKSIKOSTATISTIK BAHASA MUNA, BAHASA CIA-CIA DAN BAHASA WOLIO DI SULAWESI TENGGARA
}

\section{(The Study of Lexicostatistics of Muna Language, Cia-Cia Language and Wolio Language in Southeast Sulawesi)}

\section{La Ode Rely}

Guru SMK Negeri 4 Gorontalo

Jalan Madura Kel. Pulubala Kec. Kota Tengah Kota Gorontalo

Mahasiswa Pendidikan Bahasa dan Sastra Indonesia

Program Pascasarjana Universitas Negeri Gorontalo

Jalan Jendral Sudirman No. 6 Kota Gorontalo

Pos-el: laoderely@yahoo.co.id

\begin{abstract}
Abstrak
Bahasa Muna, bahasa Cia-Cia dan bahasa Wolio merupakan bahasa yang serumpun di Sulawesi Tenggara dan memiliki kekerabatan antara satu sama lainnya. Penelitian ini bertujuan untuk mengetahui tingkat kekerabatan bahasa Muna, bahasa Cia-Cia dan bahasa Wolio di Sulawesi Tenggara, kapan waktu pisah antara bahasa Muna, bahasa Cia-Cia dan bahasa Wolio di Sulawesi Tenggar, perkiraan usia antara bahasa Muna, bahasa Cia - Cia dan bahasa Wolio di Sulawesi Tenggara. Metode yang digunakan yaitu metode deskriptif dan menggunakan teknik leksikostatistik. Hasil penelitian menunjukan bahwa persentase kekerabatan bahasa Muna dan bahasa Cia-Cia sebesar $48 \%$. Waktu pisah antara bahasa Muna dan bahasa Cia-Cia diperkirakan sekitar tahun 183 sampai tahun 463 Masehi. Persentase kekerabatan bahasa Muna dan bahasa Wolio sebesar 45\%. Waktu pisah antara bahasa Muna dan bahasa Wolio diperkirakan sekitar tahun 23 Masehi sampai tahun 323 Masehi. Persentase kekerabatan Bahasa Cia-Cia dan bahasa Wolio sebesar 44\%. Waktu pisah antara bahasa Cia-Cia dan bahasa Wolio diperkirakan sekitar tahun 28 Sebelum Masehi sampai tahun 274 Masehi. Usia bahasa Muna sekitar tahun 183 sampai tahun 463 Masehi saat berpisah dari bahasa Induknya bersama bahasa Cia-Cia dan tahun 23 Masehi sampai tahun 323 Masehi saat berpisah dari bahasa Induknya bersama bahasa Wolio. Bahasa Muna, bahasa Cia-Cia dan bahasa Wolio termasuk satu family atau satu keluarga bahasa.
\end{abstract}

Kata kunci: Leksikostatistik, bahasa Muna, bahasa Cia-Cia, bahasa Wolio 


\begin{abstract}
The Muna language, Cia-Cia language and Wolio language are cognate languages in Southeast Sulawesi and they have kinship with each other.This researc aimed to know the level of kinship between Muna language, Cia-Cia language and Wolio language in Southeast Sulawesi, when Muna language separate from, Cia-Cia language and Wolio language, and what is the estimated age among the Muna language, Cia - Cia language and Wolio. Descriptive method and lexicostatistics technique are used in this research. The result showed that the percentage of kinship of Muna language and Cia-Cia language was 48\%. Separate time between Muna language and Cia-Cia language is estimated from 183 to 463 Masehi. The percentage of kinship of Muna language and Wolio language was 45\%. Separate time between the Muna language and Wolio language is estimated 23 Masehi until 323 Masehi. The percentage of kinship of Cia-Cia language and Wolio languages was 44\%. Separate time between Cia-Cia language and Wolio language is estimated 28 Before Masehi to 274 Masehi. The age of Muna language around 183 to 463 Masehi was separated from it's mother tongue with Cia-Cia Language and around 23 Masehi to 323 Masehi was separated from it's mother tongue with Wolio language. They were cognate language, one family or one language family.
\end{abstract}

Keywords: Lexicostatistics, Muna language, Cia-Cia language, language Wolio

\section{PENDAHULUAN}

$\begin{array}{rcr}\text { Kehidupan } & \text { Salah satu } & \text { metode } \\ \text { pengelompokan } & \text { bahasa } & \text { adalah }\end{array}$

leksikostatistik. "Leksikostatistik merupakan suatu teknik dalam pengelompokan bahasa yang lebih cenderung mengutamakan peneropongan kata-kata (leksikon) secara statistik, untuk kemudian berusaha menetapkan pengelompokan itu berdasarkan persentase kesamaan dan perbedaan suatu bahasa dengan bahasa lain" (Keraf, 1984:121). Hal tersebut tidak jauh berbeda dengan pendapat Kridalaksana (2001:127) yang mengemukakan bahwa "leksikostatistik merupakan penerapan teknik-teknik statistik dalam masalah-masalah linguistik historis untuk menduga waktu perpisahan bahasabahasa kerabat". Leksikostatistik sangat berguna untuk mengetahui seberapa besar tingkat kekerabatan bahasa-bahasa, waktu pisah serta perkiraan usia bahasa-bahasa.

"Bahasa-bahasa yang berasal dari satu induk, memiliki hubungan kekerabatan pada zaman lampau. Hal ini ditunjukan dengan adanya persamaan bentuk dan makna yang merupakan pantulan dari sejarah warisan yang sama" (Keraf, 1984:34). Olehnya itu, kajian leksikostatistik sangat cocok dilakukan pada bahasa-bahasa yang serumpun, karena bahasa-bahasa serumpun 
memiliki bahasa Proto atau bahasa Induk yang sama. Salah satunya ialah rumpun bahasa Muna-Buton, yang diantaranya bahasa Muna, bahasa Cia-Cia dan bahasa Wolio.

Hal di atas sesuai dengan pendapat Soeparno (2002:5) yang mengatakan bahwa "fungsi umum bahasa adalah sebagai alat komunikasi sosial”. Dengan demikian, setiap masyarakat dipastikan memiliki dan menggunakan alat komunikasi tersebut. Jadi, bahasa senantiasa perlu dibina, dikembangkan dan dilestarikan sehingga mampu mengikuti perkembangan zaman.

Bahasa Muna, bahasa Cia-Cia dan bahasa Wolio memiliki hubungan kekerabatan, baik dilihat dari bentuknya maupun dilihat dari maknanya. Akan tetapi seiring dengan perkembangan zaman, ketiga bahasa ini mulai jarang digunakan. Akibatnya ketiga bahasa ini terancam mengalami kepunahan.

"Bahasa Muna merupakan salah satu bahasa daerah yang ada di Sulawesi Tenggara yang masuk dalam rumpun bahasa Austronesia tepatnya rumpun Austronesia Barat Daya" (Nurhayati, 2010:1). Selanjutnya, Hanan (2014:1) mengemukakan bahwa "bahasa Cia-Cia merupakan salah satu bahasa yang dituturkan oleh sebagian besar masyarakat di bagian Selatan pulau Buton, provinsi Sulawesi Tenggara. Selanjutnya,
Ino (2009:1) mengemukakan bahwa "bahasa Wolio merupakan salah satu bahasa daerah di Sulawesi Tenggara yang cukup potensial pada zaman kerajaan atau kesultanan Buton dan sampai saat ini bahasa Wolio masih menjadi alat komunikasi bagi masyarakat pemakainya di kabupaten Buton".

Meskipun ketiga bahasa tersebut pada umumnya berbeda, ditemukan pula persamaan-persamaan dari ketiga bahasa tersebut. Contoh kata bahasa Muna dan bahasa Cia-Cia yang memiliki kesamaan dan perbedaan bentuk antara lain; (1) kata 'awan' dalam bahasa Muna "olu” dalam bahasa CiaCia "olu" yang berarti bentuk sama makna sama; (2) kata 'laut' dalam bahasa Muna "tehi" dalam bahasa Cia-Cia "tai" yang berarti bentuk berbeda makna sama. Selanjutnya, kesamaan dan perbedaan bentuk dalam bahasa Muna dan bahasa Wolio antara lain; (1) kata 'banyak' dalam bahasa Muna "bhari" dalam bahasa Wolio "bhari" yang berarti bentuk sama makna sama; (2) kata 'cium' dalam bahasa Muna "wono" dalam bahasa Wolio "taikia" yang berarti bentuk berbeda makna sama. Selanjutnya, kesamaan dan perbedaan bentuk antara bahasa Cia-Cia dan bahasa Wolio antara lain; (1) kata 'ibu' dalam bahasa Cia-Cia "ina" dalam bahasa Wolio "ina" yang berarti bentuk sama makna sama; (2) kata 'gemuk' dalam bahasa Cia- 
Cia "toowa" dalam bahasa Wolio "maoge" yang berarti bentuk berbeda makna sama.

Berdasarkan contoh perbedaan dan persamaan dari kosa kata dasar tersebut, bahasa Muna, bahasa Cia-Cia dan bahasa Wolio dapat dikatakan memiliki kekerabatan satu sama lainnya tetapi tingkat kekerabatan dari ketiga bahasa itu belum diketahui. Hal ini sepadan dengan pendapat Keraf (1984:34) yang mengatakan bahwa:

"Bahasa-bahasa kerabat yang berasal dari bahasa Proto yang sama selalu akan memperlihatkan kesamaan-kesamaan berikut; (1) kesamaan sistem bunyi (fonetik) dan susunan bunyi (fonologis); (2) kesamaan morfologis, yaitu kesamaan dalam bentuk kata dan kesamaan dalam bentuk gramatikal; (3) kesamaan sintaksis, kesamaan relasi antara kata-kata dalam sebuah kalimat".

Selain itu, tidak adanya bukti tertulis perkiraan usia dan waktu berpisah bahasa Muna, bahasa Cia-Cia dan bahasa Wolio dari bahasa Proto atau bahasa Induk belum diketahui pula. Berkenaan dengan hal tersebut, peneliti ingin mengkaji lebih dalam untuk melihat tingkat kekerabatan bahasa, waktu pisah bahasa, dan sekaligus perkiraan usia antara ketiga bahasa tersebut dengan menggunakan teknik leksikostastitik.

Berdasarkan uraian di atas penelitian ini bertujuan (1) mendeskripsikan tingkat kekerabatan bahasa Muna, bahasa Cia-Cia dan bahasa Wolio di Sulawesi Tenggara; (2) mendeskripsikan waktu pisah bahasa Muna, bahasa Cia-Cia dan bahasa Wolio di Sulawesi Tenggara; (3) mendeskripsikan perkiraan usia bahasa Muna, bahasa Cia-Cia dan bahasa Wolio di Sulawesi Tenggara.

\section{TEORI}

\section{1) Leksikostatistik}

"Leksikostatistik merupakan suatu teknik dalam pengelompokan bahasa yang cenderung mengutamakan peneropongan kata-kata (leksikon) secara statistik, untuk kemudian berusaha menetapkan pengelompokan itu berdasarkan persentase kesamaan dan perbedaan suatu bahasa dengan bahasa lain" (Keraf, 1984:121). Selanjutnya menurut Kridalaksana (2001:127) "leksikostatistik merupakan penerapan teknik-teknik statistik dalam masalah-masalah linguistik historis untuk menduga waktu perpisahan bahasa-bahasa kerabat". Jadi leksikostatistik merupakan teknik pengelompokan bahasa-bahasa kerabat dengan menggunakan teknik-teknik statistik guna mengetahui tingkat kekerabatan, waktu pisah serta perkiraan usia bahasa-bahasa tersebut. 
a) Asumsi Dasar Leksikostatistik

Menurut Keraf (1984:123; Ibrahim, 1984:63) asumsi dasar leksikostatistik adalah sebagai berikut.

1. Sebagian dari kosa kata suatu bahasa sukar sekali berubah bila dibandingkan dengan bagian lainnya.

Kata-kata yang sukar sekali berubah ini disebut kosa kata dasar. Kosa kata dasar itu merupakan kata-kata yang sangat intim, dan sekaligus merupakan unsur mati hidupnya suatu bahasa. Kosa kata dasar yang diambil dalam teknik leksikostatistik dibatasi jumlahnya, setelah diadakan penilaian yang ketat dan pengujian-pengujian untuk menerapkan teknik ini secara baik. Kosa kata dasar yang disusun harus bersifat universal, artinya kosa kata yang dianggap harus ada pada semua bahasa sejak awal mula perkembangannya.

Kosa kata dasar yang dimaksud dalam paparan di atas meliputi:

a) Kata-kata ganti berupa kamu, kami, kita dan lain sebagainya. Kata-kata ganti bersifat universal karena dianggap semua bahasa memiliki kata ganti;

b) Kata-kata bilangan berupa satu, dua, tiga, empat dan lain sebagainya. Kata-kata bilangan bersifat universal karena dianggap semua bahasa memiliki kata bilangan;

c) Kata-kata mengenai anggota badan berupa mata, mulut, hidung dan lain sebagainya. Kata-kata mengenai anggota badan bersifat universal karena dianggap semua bahasa memiliki kata mengenai anggota badan;

d) Alam dan sekitarnya berupa udara, langit, air dan lain sebagainya. Kata-kata mengenai alam dan sekitarnya bersifat universal karena dianggap semua bahasa memiliki kata mengenai alam dan sekitarnya;

e) Alat-alat perlengkapan sehari-hari yang sudah ada sejak permulaan berupa tongkat, pisau, rumah dan lain sebagainya. Kata-kata mengenai alat-alat perlengkapan sehari-hari bersifat universal karena dianggap semua bahasa memiliki kata mengenai alat-alat perlengkapan sehari-hari.

2. Retensi (ketahanan) kosa kata dasar adalah konstan atau tetap sepanjang masa Asumsi dasar yang kedua mengatakan bahwa dari kosa kata dasar yang ada dalam suatu bahasa, suatu persentase tertentu selalu akan bertahan dalam 1.000 
tahun. Kalau asumsi ini diterima, maka implikasinya adalah bahwa dari 300 kosa kata dasar yang dimiliki sebuah bahasa, sesudah 1.000 tahun akan bertahan sekian persen, dan dari sisanya sesudah 1.000 tahun kemudian akan bertahan lagi dengan persentase yang sama.

3. Perubahan kosa kata dasar pada semua bahasa adalah sama

Asumsi ketiga ini telah diuji dalam 13 bahasa, diantaranya ada yang memiliki naskah-naskah tertulis. Hasilnya menunjukan bahwa dalam tiap 1.000 tahun, kosa kata dasar suatu bahasa bertahan antara 86,4$74,4 \%$ atau dengan angka rata-rata $80,5 \%$.

4. Bila persentase dari dua bahasa kerabat diketahui, dapat dihitung waktu pisah kedua bahasa tersebut dari bahasa purbanya.

\section{b) Teknik Leksikostatistik}

Menurut Keraf (1984:126; Ibrahim, 1984:65) adapun teknik leksikostatistik yaitu sebagai berikut.

1) Mengumpulkan kosa kata dasar bahasa kerabat

Unsur yang paling penting dalam membandingkan dua bahasa atau lebih adalah mengumpulkan kosa kata dasar dari bahasa-bahasa yang akan diteliti. Daftar yang baik adalah daftar yang disusun oleh Morris Swadesh yang berisi 200 kata. Daftar tersebut membawa keuntungan dalam penelitian, karena terdiri dari kata-kata yang non-kultural serta retensi kata dasarnya telah diuji dalam bahasa-bahasa yang memiliki naskah-naskah tertulis. Tetapi ternyata bahwa ada beberapa kata yang tidak dapat dianggap universal, karena hanya terdapat pada beberapa daerah tertentu. Sehingga daftar tersebut disusun dengan memasukkan juga kata-kata yang dipergunakan oleh Kern (dalam Keraf, 1984:142) sehingga menjadi 300 kosa kata dasar.

2) Menghitung kata kerabat

Untuk menetapkan kata-kata yang berkerabat dari bahasa-bahasa yang diselidiki, hendaknya diikuti prosedurprosedur berikut.

\section{a) Gloss yang tidak diperhitungkan}

Gloss yang tidak diperhitungkan itu adalah gloss yang tidak memiliki bentuk yang menjadi realisasinya (kosong), atau kata yang tidak terdapat dalam salah satu bahasa maupun semua bahasa yang diperbandingkan. Termasuk gloss yang tidak diperhitungkan tersebut adalah gloss yang realisasinya merupakan bentuk-bentuk serapan dari bahasa lain. 
b) Pengisolasian morfem terikat

Bila dalam data-data yang telah dikumpulkan terdapat morfem-morfem terikat (awalan, sisipan dan akhiran), maka sebelum mengadakan perbandingan untuk mendapatkan kata kerabat atau non-kerabat, semua morfem terikat itu harus diisolir atau dipisahkan.

c) Penetapan kata kerabat

Bila kedua prosedur di atas telah dikerjakan, baru dimulai antara perbandingan
Kata dasar bahasa Muna Bapak Ama

(2) Pasangan itu memiliki korespondensi fonemis

Bila perubahan fonemis antara kedua bahasa itu terjadi secara timbal balik dan antara pasangan-pasangan kata dalam bahasa-bahasa tersebut, untuk menetapkan apakah pasangan itu berkerabat atau tidak. Sebuah pasangan kata akan dinyatakan sebagai kata kerabat apabila memenuhi ketentuan berikut.

(1) Pasangan itu identik

Pasangan kata yang identik adalah pasangan kata yang semua fonemnya sama betul, misalnya:

$\begin{array}{llll}\text { Kata dasar } & \text { bahasa Muna } & \text { bahasa Cia-Cia } & \text { bahasa Wolio } \\ \text { Kulit } & \text { Kuli } & \text { Sili } & ----- \\ \text { Air } & \text { Oe } & ----- & \text { Ouwe } \\ \text { Busuk } & ----- & \text { Mbuto } & \text { Mabuto }\end{array}$

(3) Kemiripan secara fonetis

Bila tidak dapat dibuktikan bahwa sebuah pasangan kata ke dalam kedua bahasa itu mengandung korespondensi fonemis, tetapi pasangan itu ternyata mengandung bahasa Cia-Cia bahasa Wolio

Ama

Ama teratur, secara tinggi frekuensinya, bentuk yang berimbang antara kedua bahasa tersebut dianggap berkerabat. Misalnya:

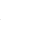




$\begin{array}{llll}\text { Kata dasar } & \text { bahasa Muna } & \text { bahasa Cia-Cia } & \text { bahasa Wolio } \\ \text { Pasir } & \text { Bhone } & \text { Hone } & \text {----- } \\ \text { Minum } & \text { Foroghu } & \text { Poghoku } & ---- \\ \text { Akar } & \text { Paraka } & \text { Pughasa } & \text { Purasa }\end{array}$

(4) Satu fonem berbeda

pengaruh lingkungan yang dimasukinya, Bila dalam satu pasangan kata maka pasangan itu dapat ditetapkan sebagai terdapat perbedaan satu fonem, tetapi dapat kata kerabat. Misalnya:

dijelaskan bahwa perbedaan itu terjadi karena

$\begin{array}{llll}\text { Kata dasar } & \text { bahasa Muna } & \text { bahasa Cia-Cia } & \text { bahasa Wolio } \\ \text { Lutut } & \text { Tuu } & \text { Cuu } & ----- \\ \text { Orang } & \text { Mie } & ----- & \text { Mia } \\ \text { Bakar } & ----- & \text { Cunu } & \text { Tunu }\end{array}$

3) Menghitung Waktu Pisah

Waktu pisah antara kedua bahasa kerabat yang telah diketahui persentase kata

$$
\mathrm{W}=\frac{\log C}{2 \log r}
$$

Keterangan:

$\mathrm{W}=$ waktu pisah dalam ribuan tahun yang lalu

$\mathrm{r}=$ retensi atau persentase konstan dalam 1000 tahun, atau disebut juga dengan indeks, dalam hal ini retensi yaitu $80,5 \%$

$\mathrm{C}=$ persentase kata kerabat

$\log =$ logaritma dari

Selanjutnya hasil terakhir dapat diubah menjadi tahun biasa setelah dikalikan 1.000 . kerabatnya, dapat dihitung dengan mempergunakan rumus sebagai berikut. 
yang lebih tepat (Novita Sari, 2012:8). Perlu diingat bahwa untuk mengantisipasi kesalahan dalam statistik adalah memberi suatu perkiraan, yakni bukan dalam waktu tertentu melainkan dalam suatu jangka waktu tertentu. Untuk menghitung jangka kesalahan dapat menggunakan rumus:

$$
S=\sqrt{\frac{C(1-C)}{n}}
$$

Keterangan:

$\mathrm{S}=$ kesalahan standar dalam persentase kata kerabat

$\mathrm{C}=$ persentase kata kerabat

$\mathrm{N}=$ jumlah kata yang diperbandingkan (baik kerabat maupun non-kerabat)

Hasil dari kesalahan standar ini dijumlahkan dengan persentase kata kerabat sebelumnya untuk mendapatkan $\mathrm{C}$ baru. Dengan $\mathrm{C}$ yang baru ini, sekali lagi dihitung waktu pisah dengan mempergunakan rumus waktu pisah. Selanjutnya waktu yang lama dikurangi dengan waktu baru. Angka inilah yang harus ditambah dan dikurangi dengan waktu yang lama untuk memperoleh usia atau waktu pisah kedua bahasa itu.

\section{2) Kekerabatan Bahasa}

Kridalaksana (2001:103) menjelaskan dalam Kamus Linguistik bahwa "kekerabatan adalah hubungan antara dua bahasa atau lebih yang diturunkan dari sumber yang sama yang disebut bahasa Purba". Hal ini tidak jauh berbeda dengan pendapat Muda (2006:306) dalam Kamus Lengkap Bahasa Indonesia yang mengungkapkan bahwa

"kekerabatan adalah perihal berkerabat atau mempunyai hubungan kekeluargaan".

Kekerabatan antara bahasa yang satu dengan bahasa yang lainnya yang masih dalam satu rumpun dapat dilihat dari perbedaan dan kemiripinnya. Semakin mirip bahasa itu, maka semakin erat hubungan kekerabatannya dan semakin berbeda kedua bahasa itu maka semakin renggang hubungan kekerabatannya.

\section{a) Rumus Menghitung Tingkat}

\section{Kekerabatan}

Untuk menentukan tingkat

kekerabatan dua bahasa digunakan rumus sebagai berikut. 
$\mathrm{C}=\frac{K}{G} X 100 \%$

Keterangan:

$\mathrm{C}=$ kata kerabat

$\mathrm{K}=$ jumlah kosakata kerabat

$\mathrm{G}=$ jumlah kata yang diperhitungkan
Setelah perhitungan persentase kata berkerabat dilakukan dan diketahui kata kerabatnya, lalu persentase itu dihubungkan dengan kategori tingkat kekerabatan bahasa. Berikut ini tabel untuk menentukan hubungan kekerabatan.

Tabel 1. Klasifikasi bahasa

\begin{tabular}{|c|c|}
\hline Tingkat Bahasa & $\begin{array}{c}\text { Persentase Kata } \\
\text { Kerabat }\end{array}$ \\
\hline Bahasa (language) & 81 ke atas \\
Keluarga (family) & $37-80$ \\
Rumpun (stock) & $12-36$ \\
Mikrofilum & $4-11$ \\
Mesofilum & $1-3$ \\
Makrofilum & 1 ke bawah \\
\hline
\end{tabular}

Sumber: Gorys Keraf (1984) Linguistik Bandingan Historis

\section{3) Konsep Usia Bahasa}

Menurut Muda (2006:557) dalam Kamus Lengkap Bahasa Indonesia "usia sama saja dengan umur". Umur atau usia adalah satuan waktu yang mengukur waktu keberadaan suatu benda atau makhluk, baik yang hidup maupun yang mati. Semisal, umur bahasa dikatakan atau diperkirakan 1520 tahun diukur sejak dia lahir atau berpisah dari bahasa Induk hingga waktu umur itu dihitung.

Usia bahasa tidak lepas dari kekerabatan bahasa. Hal ini sesuai dengan pendapat Keraf (1984:124) pada poin empat yang mengemukakan bahwa "bila persentase dari dua bahasa kerabat diketahui, maka dapat dihitung waktu pisah kedua bahasa tersebut". Waktu pisah yang dimaksud adalah usia atau waktu pisah bahasa kerabat dari bahasa Induk atau bahasa Proto. Jadi, usia atau umur bahasa merupakan lamanya keberadaan suatu bahasa sejak bahasa itu muncul atau berpisah dari bahasa induk atau bahasa Protonya. 


\section{METODE PENELITIAN}

"Metode penelitian merupakan cara ilmiah untuk memperoleh, mengembangkan dan memverifikasi pengetahuan atau teori” (Suharsaputra, 2012:19). Penelitian ini adalah penelitian gabungan kualitatif dan kuantitatif dengan metode deskriptif dan menggunakan teknik leksikostatistik. Jadi dalam penelitian ini, kekerabatan bahasa Muna, bahasa Cia-Cia dan bahasa Wolio akan dijelaskan dan dideskripsikan. Selanjutnya untuk menghitung tingkat kekerabatan, waktu pisah dan usia bahasa menggunakan rumus-rumus dengan teknik leksikostatistik.

Penelitian ini dilakukan di tiga tempat yakni di desa Lakologou kecamatan Tongkuno kabupaten Muna, desa Lapodi kecamatan Pasar Wajo kabupaten Buton, kelurahan Wangkanapi kecamatan Wolio kota Bau-Bau. Selanjutnya, objek dalam penelitian ini adalah bahasa Muna, bahasa Cia-Cia dan bahasa Wolio yang terdapat di wilayah pemakai bahasa masing-masing. Data dalam penelitian adalah 300 kosakata dasar menurut Swadesh dan Kern yang sudah universal dan dituturkan oleh masing-masing informan

Informan adalah orang yang memberikan data penelitian. Mahsun (2012:141) menegaskan bahwa syarat-syarat informan adalah 1) Berjenis kelamin pria atau wanita; 2) Berusia antara 25-65 tahun (tidak pikun); 3) Orang tua, istri, atau suami yang lahir dan dibesarkan di desa tersebut serta jarang atau tidak pernah meninggalkan desanya; 4) Berpendidikan maksimal tamat pendidikan dasar (SD-SLTP); 5) Berstatus sosial menengah (tidak rendah atau tidak tinggi) dengan harapan tidak terlalu tinggi mobilitasnya; 6) Pekerjannya bertani dan buruh; 7) Dapat berbahasa Indonesia; 8) Sehat jasmani dan rohani.

Berdasarkan kriteria informan yang dikemukakan oleh Mahsun tersebut, maka peneliti menetapkan kriteria informan 1) Berjenis kelamin pria atau wanita; 2) Berusia antara 25-65 tahun (tidak pikun); 3) Orang tua, istri, atau suami yang lahir dan dibesarkan di desa tersebut serta jarang atau tidak pernah meninggalkan desanya; 4) Berstatus sosial menengah (tidak rendah atau tidak tinggi) dengan harapan tidak terlalu tinggi mobilitasnya; 5) Dapat berbahasa Indonesia; 6) Sehat jasmani dan rohani.

Teknik pengumpulan data yang dilakukan dalam penelitian ini adalah sebagai berikut.

1) Teknik Wawancara

"Wawancara adalah percakapan dengan maksud tertentu yang dilakukan oleh dua pihak" (Moleong, 2012:186). Teknik wawancara digunakan peneliti untuk 
mendapatkan kebenaran lebih lanjut dan terperinci tentang data yang dibutuhkan. Wawancara yang digunakan adalah wawancara terstruktur. Menurut Afifuddin dan Saebani (2009:133) "wawancara terstruktur adalah wawancara yang pertanyaan-pertanyaannya telah disiapkan, seperti menggunakan pedoman wawancara". Peneliti menggunakan pedoman wawancara yang berisi 300 pertanyaan berupa kosa kata dasar yang telah disiapkan sebelumnya. Peneliti melakukan wawancara kepada informan sesuai dengan kriteria informan yang telah ditetapkan. Wawancara dilakukan pada saat informan benar-benar siap untuk diwawancarai.

\section{2) Teknik Rekam}

Teknik rekam dilakukan ketika peneliti memberikan pertanyaan yang berhubungan dengan penelitian kepada informan. Peneliti akan merekam secara keseluruhan jawaban yang diberikan oleh informan. Jawaban itu berupa kosa kata dasar dalam bahasa Muna, bahasa Cia-Cia maupun bahasa Wolio berdasarkan kosa kata Swades dan Kern.
3) Teknik Catat

Peneliti menggunakan teknik catat untuk mencatat semua jawaban yang diberikan oleh informan serta hal-hal penting yang terjadi selama komunikasi berlangsung. Kegiatan ini dilakukan untuk memperoleh data sealamiah mungkin. Selain itu, peneliti juga akan mencatat identitas siapa saja yang akan menjadi informan. Peneliti juga akan mentranskripsikan hasil rekaman ke dalam tulisan untuk menyesuaikan data yang diperoleh melalui teknik catat dan teknik rekam.

Setelah dikumpulkan 300 kosa kata dasar Swadesh dan Kern dari bahasa Muna, bahasa Cia-Cia dan bahasa Wolio selanjutnya dilakukan analisis sebagai berikut.

1) Mengumpulkan kosa kata dasar bahasa yang berkerabat, dengan ketentuan sebagai berikut.
a. Pasangan identik; korespondensi fonemis;
c. Kemiripan secara fonetis;
d. Satu fonem berbeda.

b. Pasangan itu memiliki

2) Menetapkan dan menghitung pasanganpasangan yang berkerabat dengan rumus

$$
\mathrm{C}=\frac{\text { jumlah kosa kata dasar kerabat }(K)}{\text { jumlah kata yang diperhitungkan }(G)} \times 100 \%
$$


3) Menghitung waktu pisah dengah rumus

$$
\mathrm{W}=\frac{\log C}{2 \log r}
$$

\section{Keterangan:}

$\mathrm{W}=$ waktu pisah dalam ribuan tahun yang lalu

$\mathrm{r}=$ retensi atau persentase konstan dalam 1000 tahun, atau disebut juga dengan indeks

$\mathrm{C}=$ persentase kata kerabat

$\log =$ logaritma dari

4) Menghitung jangka kesalahan dengan

rumus

$$
S=\sqrt{\frac{C(1-C)}{n}}
$$

Keterangan:

$\mathrm{S}=$ kesalahan standar dalam persentase kata kerabat

$\mathrm{C}=$ persentase kata kerabat

$\mathrm{n}=$ jumlah kata yang diperbandingkan (baik kerabat maupun non-kerabat)

5) Menganalisis data yang telah terkumpul kekerabatan diketahui, dapat ditentukan dalam bentuk uraian atau penjelasan. tingkat kekerabatan antara bahasa Muna, bahasa Cia-Cia dan bahasa Wolio.

6) Menyimpulkan data yang telah dianalisis.

\section{HASIL PENELITIAN DAN}

PEMBAHASAN

Setelah menentukan kata berkerabat melalui perbandingan kata secara berpasangan, dapat ditentukan persentase kekerabatan antara bahasa Muna, bahasa CiaCia dan bahasa Wolio. Setelah persentase

\section{1) Tingkat kekerabatan bahasa Muna dan bahasa Cia-Cia}

Berdasarkan perbandingan kata secara berpasangan antara bahasa Muna dan bahasa Cia-Cia terdapat 37 kata kerabat yang tergolong identik, 55 kata kerabat yang tergolong korespondensi fonemis, 41 kata kerabat yang tergolong kemiripan secara 
fonetis dan 10 kata kerabat yang tergolong satu fonem berbeda. Sehingga 143 kata dinyatakan berkerabat, 152 kata dinyatakan tidak berkerabat dan 5 kata dinyatakan tidak memiliki pasangan. Berdasarkan hal tersebut, persentase kekerabatan antara bahasa Muna dan bahasa Cia-Cia dapat ditentukan dengan rumus sebagai berikut.

$$
\begin{aligned}
& \mathrm{C}=\frac{K}{G} X 100 \% \Rightarrow \mathrm{C}=\frac{143}{295} X 100 \% \\
& \mathrm{C}=48,47 \text { atau dibulatkan menjadi } 48 \%
\end{aligned}
$$

Berdasarkan hasil yang diperoleh, tergolong identik, 85 kata kerabat yang persentase kekerabatan antara bahasa Muna tergolong korespondensi fonemis, 17 kata dan bahasa Cia-Cia yaitu 48\% maka tingkat kerabat yang tergolong kemiripan secara kekerabatan antara bahasa Muna dan bahasa fonetis dan 8 kata kerabat yang tergolong Cia-Cia berada pada satu family atau satu satu fonem berbeda. 133 kata dinyatakan keluarga bahasa. (lihat tabel 1, hal: 10) berkerabat, 164 kata dinyatakan tidak berkerabat dan 3 kata dinyatakan tidak

2) Tingkat kekerabatan bahasa Muna memiliki pasangan. Berdasarkan hal tersebut, dan bahasa Wolio persentase kekerabatan antara bahasa Muna

Berdasarkan perbandingan kata dan bahasa Wolio dapat ditentukan dengan secara berpasangan antara bahasa Muna dan rumus sebagai berikut. bahasa Wolio terdapat 23 kata kerabat yang

$$
\begin{aligned}
& \mathrm{C}=\frac{K}{G} X 100 \% \Rightarrow \mathrm{C}=\frac{133}{297} X 100 \% \\
& \mathrm{C}=44,78 \text { atau dibulatkan menjadi } 45 \%
\end{aligned}
$$

Berdasarkan hasil yang diperoleh, persentase kekerabatan antara bahasa Muna dan bahasa Wolio yaitu 45\% maka tingkat kekerabatan antara bahasa Muna dan bahasa Wolio berada pada satu family atau satu keluarga bahasa. (lihat tabel 1, hal: 10)

\section{3) Tingkat kekerabatan bahasa Cia-Cia dan bahasa Wolio}

Berdasarkan perbandingan kata secara berpasangan antara bahasa Cia-Cia dan bahasa Wolio terdapat 18 kata kerabat yang tergolong identik, 101 kata kerabat yang tergolong korespondensi fonemis, 8 
kata kerabat yang tergolong kemiripan secara fonetis dan 3 kata kerabat yang tergolong satu fonem berbeda. Sehingga 130 kata dinyatakan berkerabat, 167 kata dinyatakan tidak berkerabat dan 3 kata dinyatakan tidak memiliki pasangan. Berdasarkan hal tersebut, persentase kekerabatan antara bahasa Cia-Cia dan bahasa Wolio dapat ditentukan dengan rumus sebagai berikut.

$$
\begin{aligned}
& \mathrm{C}=\frac{K}{G} X 100 \% \Rightarrow \mathrm{C}=\frac{130}{297} X 100 \% \\
& \mathrm{C}=43,77 \text { atau dibulatkan menjadi } 44 \%
\end{aligned}
$$

Berdasarkan hasil yang diperoleh, dihitung setelah diketahui persentase kata persentase kekerabatan antara bahasa Cia-Cia kerabatnya. dan bahasa Wolio yaitu 44\% maka tingkat kekerabatan antara bahasa Cia-Cia dan bahasa Wolio berada pada satu family atau satu keluarga bahasa. (lihat tabel 1, hal: 10)

\section{a) Waktu Pisah antara bahasa Muna dan bahasa Cia-Cia}

Setelah mengetahui persentase kekerabatan antara bahasa Muna dan bahasa

4) Waktu Pisah antara bahasa Muna, bahasa Cia-Cia dan bahasa Wolio

Cia-Cia maka waktu pisah antara kedua bahasa tersebut yaitu sebagai berikut.

Waktu pisah antara bahasa Muna, bahasa Cia-Cia dan bahasa Wolio dapat

$$
\begin{aligned}
\text { Dik. } \mathrm{C}=48 \% & \Rightarrow \mathrm{C}=0,48 \quad \rightarrow \log \mathrm{C}=-0,734 \\
\mathrm{r}=80,5 \% & \Rightarrow \mathrm{r}=0,805 \rightarrow \log \mathrm{r}=-0,217
\end{aligned}
$$

Dit. $\mathrm{W}=\ldots$. ?

$$
\mathrm{W}=\frac{\log C}{2 \log r}=\frac{-0,734}{2 x(-0,217)}=\frac{-0,734}{2 x(-0,217)}=\frac{-0,734}{-0,434}=1,691
$$

Setelah waktu pisah antara bahasa menghindari kesalahan perhitungan serta Muna dan bahasa Cia-Cia diketahui hasilnya, menetapkan waktu pisah yang lebih tepat. langkah selanjutnya yaitu menghitung jangka Menghitung jangka kesalahan menggunakan kesalahan. Hal ini dilakukan untuk rumus sebagai berikut. 


$$
\begin{aligned}
& \mathrm{S}=\sqrt{\frac{C(1-C)}{n}} \Longrightarrow \mathrm{S}=\sqrt{\frac{0,48(1-0,48)}{295}} \\
& \mathrm{~S}=\sqrt{\frac{0,48 \times 0,52}{295}} \Longrightarrow \mathrm{S}=\sqrt{\frac{0,2496}{295}} \Longrightarrow \mathrm{S}=\sqrt{0,00084} \\
& \mathrm{~S}=0,029 \text { atau dibulatkan menjadi } 0,03
\end{aligned}
$$

Hasil dari kesalahan standar yaitu $0,48+0,03=0,51$. Selanjutnya waktu ditambahkan dengan persentase kerabat (C) pisah kembali dihitung dengan $\mathrm{C}$ yang baru. sebelumnya untuk mendapatkan $\mathrm{C}$ baru,

$$
\begin{aligned}
\text { Dik. } \mathrm{C} & =0,51 \quad \Rightarrow \log \mathrm{C}=-0,673 \\
\mathrm{r} & =0,805 \quad \Rightarrow \log \mathrm{r}=-0,217
\end{aligned}
$$

Dit. $\mathrm{W}=\ldots$ ?

$$
\mathrm{W}=\frac{\log C}{2 \log r}=\frac{-0,673}{2 x(-0,217)}=\frac{-0,673}{2 x(-0,217)}=\frac{-0,673}{-0,434}=1,551
$$

Hasil terakhir dapat diubah menjadi tahun biasa setelah dikalikan 1.000. Sehingga hasilnya menjadi 1.551. Dengan demikian, jangka kesalahan yaitu $\mathrm{W}$ awal $-\mathrm{W}$ akhir = $1.691-1.551=140$

Berdasarkan hasil perhitungan di atas, waktu pisah antara bahasa Muna dan bahasa Cia-Cia yaitu sebagai berikut.

1) Bahasa Muna dan bahasa Cia-Cia diperkirakan merupakan satu bahasa tunggal sekitar $1.691 \pm 140$ tahun yang lalu. 
Dit. $\mathrm{W}=\ldots . . ?$

$$
\mathrm{W}=\frac{\log C}{2 \log r}=\frac{-0,799}{2 x(-0,217)}=\frac{-0,799}{2 x(-0,217)}=\frac{-0,799}{-0,434}=1,841
$$

Setelah waktu pisah antara bahasa menetapkan waktu pisah yang lebih tepat. Muna dan bahasa Wolio diketahui hasilnya, Menghitung jangka kesalahan menggunakan langkah selanjutnya yaitu menghitung jangka rumus sebagai berikut.

kesalahan. Hal ini dilakukan untuk menghindari kesalahan perhitungan serta

$$
\begin{aligned}
& \mathrm{S}=\sqrt{\frac{C(1-C)}{n}} \Longrightarrow \mathrm{S}=\sqrt{\frac{0,45(1-0,45)}{297}} \\
& \mathrm{~S}=\sqrt{\frac{0,45 \times 0,55}{297}} \Longrightarrow \mathrm{S}=\sqrt{\frac{0,2475}{297}} \Rightarrow \mathrm{S}=\sqrt{0,00083} \\
& \mathrm{~S}=0,028 \text { atau dibulatkan menjadi } 0.03
\end{aligned}
$$

Hasil dari kesalahan standar yaitu $0,45+0,03=0,48$. Selanjutnya waktu ditambahkan dengan persentase kerabat (C) pisah kembali dihitung dengan $\mathrm{C}$ yang baru. sebelumnya untuk mendapatkan C baru, 


$$
\begin{aligned}
\text { Dik. } \mathrm{C}=0,48 & \Rightarrow \log \mathrm{C}=-0,734 \\
\mathrm{r} & =0,805 \quad \Rightarrow \log \mathrm{r}=-0,217
\end{aligned}
$$

Dit. $\mathrm{W}=\ldots$. ?

$$
\mathrm{W}=\frac{\log C}{2 \log r}=\frac{-0,734}{2 x(-0,217)}=\frac{-0,734}{2 x(-0,217)}=\frac{-0,734}{-0,434}=1,691
$$

Hasil terakhir dapat diubah menjadi tahun biasa setelah dikalikan 1.000. Sehingga hasilnya menjadi 1.691. Dengan demikian, jangka kesalahan yaitu $\mathrm{W}$ awal $-\mathrm{W}$ akhir $=$ $1.841-1.691=150$

Berdasarkan hasil perhitungan di atas, maka waktu pisah antara bahasa Muna dan bahasa Wolio yaitu sebagai berikut.

1) Bahasa Muna dan bahasa Wolio diperkirakan merupakan satu bahasa tunggal sekitar $1.841 \pm 150$ tahun yang lalu.
2) Bahasa Muna dan bahasa Wolio merupakan bahasa tunggal pada 1991 1.691 tahun yang lalu.

3) Bahasa Muna dan bahasa Wolio diperkirakan mulai berpisah dari bahasa induknya sekitar tahun 23 Masehi sampai tahun 323 Masehi (dihitung pada tahun 2014).

c) Waktu Pisah antara bahasa Cia-

\section{Cia dan bahasa Wolio}

Setelah mengetahui persentase kekerabatan antara bahasa Cia-Cia dan bahasa Wolio maka waktu pisah antara kedua bahasa tersebut yaitu sebagai berikut.

$$
\begin{aligned}
\text { Dik. } \mathrm{C}=44 \% & \rightarrow \mathrm{C}=0,44 \rightarrow \log \mathrm{C}=-0,821 \\
\mathrm{r}=80,5 \% & \rightarrow \mathrm{r}=0,805
\end{aligned}
$$

Dit. $\mathrm{W}=\ldots$ ?

$$
\mathrm{W}=\frac{\log C}{2 \log r}=\frac{-0,821}{2 x(-0,217)}=\frac{-0,821}{2 x(-0,217)}=\frac{-0,821}{-0,434}=1,891
$$

Setelah waktu pisah antara bahasa perhitungan serta menetapkan waktu pisah Cia-Cia dan bahasa Wolio diketahui yang lebih tepat. Menghitung jangka hasilnya, langkah selanjutnya yaitu kesalahan menggunakan rumus sebagai menghitung jangka kesalahan. Hal ini berikut. dilakukan untuk menghindari kesalahan 


$$
\begin{aligned}
& \mathrm{S}=\sqrt{\frac{C(1-C)}{n}} \Longrightarrow \mathrm{S}=\sqrt{\frac{0,44(1-0,44)}{297}} \\
& \mathrm{~S}=\sqrt{\frac{0,44 \times 0,56}{297}} \Longrightarrow \mathrm{S}=\sqrt{\frac{0,2464}{297}} \Rightarrow \mathrm{S}=\sqrt{0,00083} \\
& \mathrm{~S}=0,029 \text { atau dibulatkan menjadi } 0.03
\end{aligned}
$$

Hasil dari kesalahan standar yaitu $0,44+0,03=0,47$. Selanjutnya waktu ditambahkan dengan persentase kerabat (C) pisah kembali dihitung dengan $\mathrm{C}$ yang baru. sebelumnya untuk mendapatkan C baru,

$$
\begin{aligned}
\text { Dik. } \mathrm{C}=0,47 & \Rightarrow \log \mathrm{C}=-0,755 \\
\mathrm{r} & =0,805 \quad \rightarrow \log \mathrm{r}=-0,217
\end{aligned}
$$

Dit. $\mathrm{W}=\ldots . ?$

$$
\mathrm{W}=\frac{\log C}{2 \log r}=\frac{-0,755}{2 x(-0,217)}=\frac{-0,755}{2 x(-0,217)}=\frac{-0,755}{-0,434}=1,740
$$

Hasil terakhir dapat diubah menjadi tahun biasa setelah dikalikan 1.000. Sehingga hasilnya menjadi 1.740. Dengan demikian, jangka kesalahan yaitu W awal - W akhir $=$ $1.891-1.740=151$

Berdasarkan hasil perhitungan di atas, maka waktu pisah antara bahasa Cia-Cia dan bahasa Wolio yaitu sebagai berikut.

1) Bahasa Cia-Cia dan bahasa Wolio diperkirakan merupakan satu bahasa tunggal sekitar $1.891 \pm 151$ tahun yang lalu.

2) Bahasa Cia-Cia dan bahasa Wolio merupakan bahasa tunggal pada 2042 1.740 tahun yang lalu.
3) Bahasa Cia-Cia dan bahasa Wolio diperkirakan mulai berpisah dari bahasa induknya sekitar tahun 28 sebelum Masehi sampai tahun 274 Masehi (dihitung pada tahun 2014).

5) Perkiraan usia bahasa Muna, bahasa Cia-Cia dan bahasa Wolio

Perkiraan usia bahasa Muna, bahasa

Cia-Cia dan bahasa Wolio dapat ditentukan setelah waktu pisah antara ketiga bahasa diketahui.

\section{a) Perkiraan usia bahasa Muna}

Berdasarkan perhitungan waktu pisah maka perkiraan usia bahasa Muna yaitu 
sekitar tahun 183 sampai tahun 463 Masehi saat berpisah dari bahasa Induknya bersama bahasa Cia-Cia dan tahun 23 Masehi sampai tahun 323 Masehi saat berpisah dari bahasa Induknya bersama bahasa Wolio.

\section{b) Perkiraan usia bahasa Cia-Cia}

Berdasarkan perhitungan waktu pisah maka perkiraan usia bahasa Cia-Cia yaitu sekitar tahun 183 sampai tahun 463 Masehi saat berpisah dari bahasa Induknya bersama bahasa Muna dan tahun 28 Sebelum Masehi sampai tahun 274 Masehi saat berpisah dari bahasa Induknya bersama bahasa Wolio.

\section{c) Perkiraan usia bahasa Wolio}

Berdasarkan perhitungan waktu pisah maka perkiraan usia bahasa Wolio yaitu sekitar tahun 23 Masehi sampai tahun 323 Masehi saat berpisah dari bahasa Induknya bersama bahasa Muna dan tahun 28 Sebelum Masehi sampai tahun 274 Masehi saat berpisah dari bahasa Induknya bersama bahasa Cia-Cia.

Berdasarkan hasil penelitian yang telah dipaparkan di atas, persentase kekerabatan bahasa Muna dan bahasa CiaCia sebesar 48\%, persentase kekerabatan bahasa Muna dan bahasa Wolio sebesar 45\%, persentase kekerabatan bahasa Cia-Cia dan bahasa Wolio sebesar 44\%. Dengan demikian, tingkat kekerabatan bahasa Muna, bahasa Cia-Cia dan bahasa Wolio berada pada satu family atau satu keluarga bahasa. Berikut ini merupakan tingkat persentase dari masing-masing bahasa.

Grafik 1. Persentase kekerabatan bahasa Muna, bahasa Cia-Cia dan bahasa Wolio.

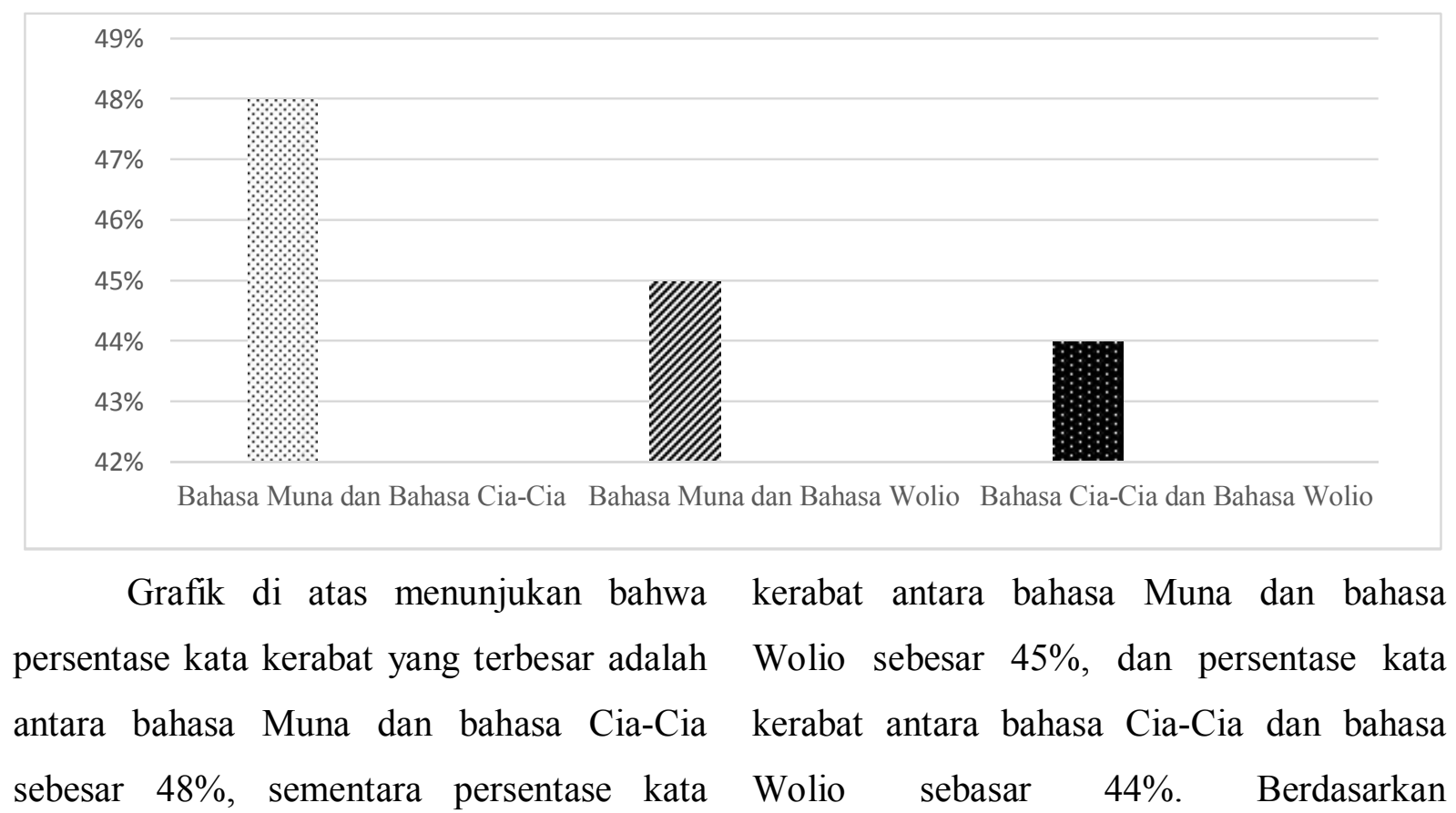


perbandingan persentase bahasa Muna dan bahasa Cia-Cia memiliki tingkat kekerabatan yang paling dekat dibandingkan dengan bahasa Muna dan bahasa Wolio maupun bahasa Cia-Cia dan bahasa Wolio.

Bahasa Muna dan bahasa Cia-Cia diperkirakan merupakan satu bahasa tunggal sekitar $1.691 \pm 140$ tahun yang lalu atau sekitar 1.831 - 1.551 tahun yang lalu. Bahasa Muna dan bahasa Cia-Cia diperkirakan mulai berpisah dari bahasa induknya sekitar tahun 183 - 463 Masehi (dihitung pada tahun 2014). Selanjutnya Bahasa Muna dan bahasa Wolio diperkirakan merupakan satu bahasa tunggal sekitar $1.841 \pm 150$ tahun yang lalu atau sekitar 1991 - 1.691 tahun yang lalu. Bahasa Muna dan bahasa Wolio diperkirakan mulai berpisah dari bahasa induknya sekitar tahun 23 Masehi sampai tahun 323 Masehi (dihitung pada tahun 2014). Selanjutnya bahasa Bahasa Cia-Cia dan bahasa Wolio yang diperkirakan merupakan satu bahasa tunggal sekitar $1.891 \pm 151$ tahun yang lalu atau sekitar 2042 - 1.740 tahun yang lalu. Bahasa Cia-Cia dan bahasa Wolio diperkirakan mulai berpisah dari bahasa induknya sekitar tahun 28 Sebelum Masehi sampai tahun 274 Masehi (dihitung pada tahun 2014). Berikut ini merupakan waktu pisah dari masing-masing bahasa.

Grafik 2.

Waktu pisah antara bahasa Muna, bahasa Cia-Cia dan bahasa Wolio dihitung pada tahun 2014.

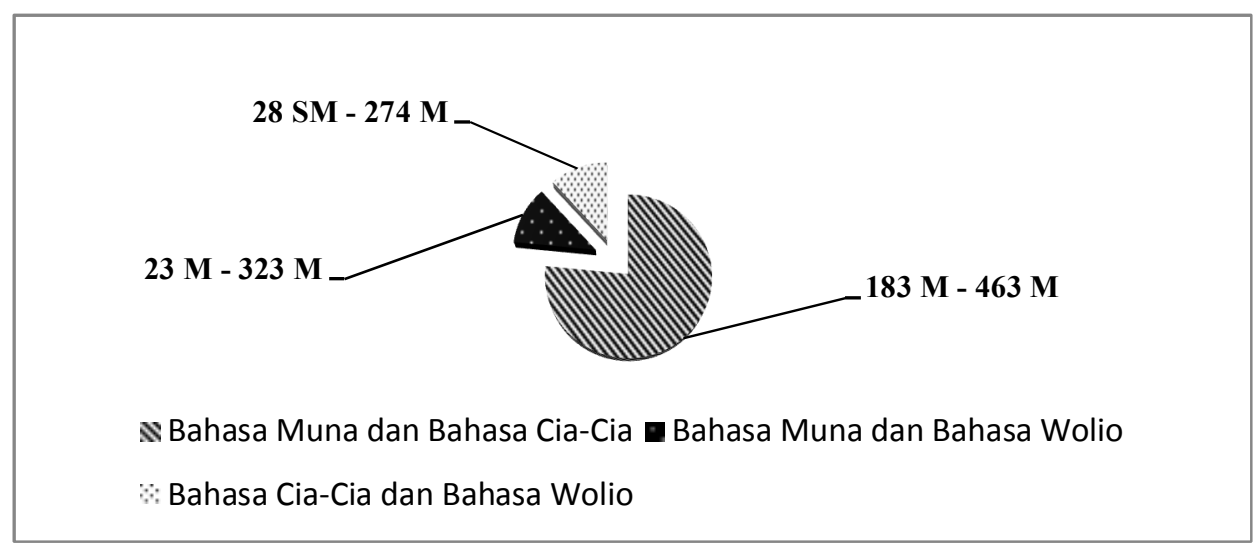

Grafik di atas menunjukan bahwa waktu pisah antara bahasa Muna dan bahasa Cia-Cia lebih dekat yaitu sekitar tahun 183 sampai tahun 463 Masehi dibandingkan dengan waktu pisah antara bahasa Muna dan bahasa Wolio yaitu sekitar tahun 23 Masehi sampai tahun 323 Masehi serta waktu pisah antara bahasa Cia-Cia dan bahasa Wolio yaitu sekitar tahun 28 Sebelum Masehi sampai tahun 274 Masehi. Selanjutnya 
perkiraan usia dapat ditentukan setelah perkiraan usia masing-masing bahasa. mengetahui waktu pisah. Berikut ini grafik

\section{Grafik 3.}

Perkiraan usia bahasa Muna, bahasa Cia-Cia dan bahasa Wolio

$28 \mathrm{SM}-274 \mathrm{SM}$

Grafik di atas menunjukan bahwa Usia bahasa Muna sekitar tahun 183 sampai tahun 463 Masehi saat berpisah dari bahasa Induknya bersama bahasa Cia-Cia dan tahun 23 Masehi sampai tahun 323 Masehi saat berpisah dari bahasa Induknya bersama bahasa Wolio dan Usia bahasa Cia-Cia sekitar tahun 183 sampai tahun 463 Masehi saat berpisah dari bahasa Induknya bersama bahasa Muna dan tahun 28 Sebelum Masehi sampai tahun 274 Masehi saat berpisah dari bahasa Induknya bersama bahasa Wolio serta Usia bahasa Wolio sekitar tahun 23 Masehi sampai tahun 323 Masehi saat berpisah dari bahasa Induknya bersama bahasa Muna dan tahun 28 Sebelum Masehi sampai tahun 274 Masehi saat berpisah dari bahasa Induknya bersama bahasa Cia-Cia. Jadi dapat disimpulkan bahwa bahasa Wolio jika dilihat dari perbandingan bahasa Muna dan bahasa Cia-Cia usianya lebih tua dibanding bahasa Muna dan bahasa Cia-Cia itu sendiri.

\section{SIMPULAN}

Berdasarkan hasil penelitian dan pembahasan yang telah diuraikan di atas, dapat disimpulkan hal-hal sebagai berikut.

1) Dari 300 kosa kata dasar yang diperbandingkan antara bahasa Muna dan bahasa Cia-Cia terdapat 5 kata yang dinyatakan tidak memiliki pasangan, 152 kata dinyatakan tidak berkerabat dan 143 kata dinyatakan berkerabat sehingga persentase kekerabatan sebesar 48\%. Waktu pisah antara bahasa Muna dan 
bahasa Cia-Cia diperkirakan sekitar tahun 183 sampai tahun 463 Masehi.

2) Dari 300 kosa kata dasar yang diperbandingkan antara bahasa Muna dan bahasa Wolio terdapat 3 kata yang dinyatakan tidak memiliki pasangan, 164 kata dinyatakan tidak berkerabat dan 133 kata dinyatakan berkerabat sehingga persentase kekerabatan sebesar $45 \%$. Waktu pisah antara bahasa Muna dan bahasa Wolio diperkirakan sekitar tahun 23 Masehi sampai tahun 323 Masehi.

3) Dari 300 kosa kata dasar yang diperbandingkan antara bahasa Cia-Cia dan bahasa Wolio terdapat 3 kata yang dinyatakan tidak memiliki pasangan, 167 kata dinyatakan tidak berkerabat dan 130 kata dinyatakan berkerabat sehingga persentase kekerabatan sebesar 44\%. Waktu pisah antara bahasa Cia-Cia dan bahasa Wolio diperkirakan sekitar tahun 28 Sebelum Masehi sampai tahun 274 Masehi.

4) Usia bahasa Muna sekitar tahun 183 sampai tahun 463 Masehi saat berpisah dari bahasa Induknya bersama bahasa Cia-Cia dan tahun 23 Masehi sampai tahun 323 Masehi saat berpisah dari bahasa Induknya bersama bahasa Wolio.

5) Usia bahasa Cia-Cia sekitar tahun 183 sampai tahun 463 Masehi saat berpisah dari bahasa Induknya bersama bahasa
Muna dan tahun 28 Sebelum Masehi sampai tahun 274 Masehi saat berpisah dari bahasa Induknya bersama bahasa Wolio.

6) Usia bahasa Wolio sekitar tahun 23 Masehi sampai tahun 323 Masehi saat berpisah dari bahasa Induknya bersama bahasa Muna dan tahun 28 Sebelum Masehi sampai tahun 274 Masehi saat berpisah dari bahasa Induknya bersama bahasa Cia-Cia.

Bahasa Muna, bahasa Cia-Cia dan bahasa Wolio termasuk satu family atau satu keluarga bahasa.

\section{DAFTAR PUSTAKA}

Afifudin dan Beni Ahmad Saebani. 2009. Metodologi penelitian kualitatif. Bandung: Pustaka Setia.

Bulu, Aldino T. 2014. Kekerabatan Bahasa Banggai, Bahasa Saluan dan Bahasa Balantak di Kota Luwuk Sulawesi Tengah. Skripsi. Universitas Negeri Gorontalo.

Berg, Rene Van Den dan La Ode Sidu. 1996. Kamus Muna - Indonesia. Belum diterbitkan.

Hanan, Sandra Safitri. 2014. Genealogi Bahasa Cia-Cia.

http://etd.ugm.ac.id/index.php?mod=downloa $\mathrm{d} \& \mathrm{sub}=$ DownloadFile\&act $=$ view \& $\mathrm{t}$ $\mathrm{yp}=\mathrm{html} \&$ file $=309778$.pdf $\&$ ftyp $=$ po tongan \& tahun $=2014 \&$ potongan $=\mathrm{S} 3$ - 
2014-309778-chapter1.pdf. 27 April 2014.

Ibrahim, Syukur. 1984. Linguistik Historis (Sajian Bunga Rampai). Surabaya: Usaha Nasional.

Ino, La. 2009. Proses Morfonologis Prefiks dalam Bahasa Wolio (Kajian Transformasi Generatif). http://idci.dikti.go.id/pdf/JURNAL/J URNAL LINGUA/VOL No. 20 JUNI 2009/PROSES MORFONOLOGIS PREFIKS DALAM BAHASA WOLIO.pdf. 24 Februari 2014.

Keraf, Gorys. 1984. Linguistik Bandingan Historis. Jakarta: PT Gramedia Pustaka Utama.

Kridalaksana, Harimurti. 2001. Kamus Linguistik (Edisi 3). Jakarta: PT Gramedia Pustaka Utama.

Mahsun. 2012. Metode Penelitian Bahasa (Tahapan Strategi, Metode dan Tekniknya) Edisi Revisi. Jakarta: Rajawali Pers.

Muda, Ahmad A.K. 2006. Kamus Lengkap Bahasa Indonesia. Surabaya: Reality Publisher.

Moleong, Lexi J. 2012. Metodologi Penelitian Kualitatif. Bandung: PT. Remaja Posdakarya.

Nurhayati. 2010. Jejak Bahasa Melayu (Indonesia) dalam Bahasa Muna. http://repository.unhas.ac.id/ 26 April 2014.

Novita Sari, Kurnia. 2012. Leksikostatistik Bahasa Aceh, Bahasa Alas dan
Bahasa Gayo: Kajian Linguistik Historis Komparatif.

http://download.portalgaruda.org/article.php? article $=74118 \& \mathrm{val}=4705.24$ Februari 2014.

Rismanto, Rendi. 2012. Kekerabatan Kosa Kata Bahasa Sunda dengan Bahasa Melayu Betawi di Kota Tanggerang Selatan: Kajian Linguistik Historis Komparatif. http://download.portalgaruda.org/art icle.php? article $=103939 \&$ val $=1378$. 24 Februari 2014.

Sinaga, Fitriana. 2007. Kajian

Leksikostatistik antara Bahasa Simalungan dan Bahasa Karo.

http://repository.usu.ac.id/bitstream/ 123456789/13350/1/09E00034.pdf. 24 Februari 2014.

Suharsaputra, Umar. 2012. Metode Penelitian (Kuantitaif, Kualitatif dan Tindakan). Bandung: PT. Refika Aditama.

Soeparno. 2002. Dasar-dasar linguistik umum. Yogyakarta: PT Tiara Wacana Yogya. 